\title{
PENGARUH ANNUAL REPORT AWARD (ARA) TERHADAP NILAI PERUSAHAAN
}

\author{
Dewi Kusuma Wardani ${ }^{1}$, Diniari Marlina Antara ${ }^{2}$ \\ ${ }^{12}$ Program Studi Akuntansi, Fakultas Ekonomi \\ Universitas Sarjanawiyata Tamansiswa Yogyakarta \\ ${ }^{1}$ Email: dewifeust@gmail.com
}

\begin{abstract}
Abstrak
Penelitian ini bertujuan untuk mengetahui pengaruh Annual Report Award (ARA) terhadap nilai perusahaan pada perusahaan yang memenangkan ARA 2013-2015 yang tercatat di Bursa Efek Indonesia. Penelitian ini merupakan penelitian studi acara selama 11 hari yaitu 5 hari sebelumnya, 1 hari pengumuman, dan 5 hari setelah pengumuman. Nilai perusahaan dalam penelitian ini diukur dengan menggunakan harga saham dan abnormal return. Harga saham yang digunakan adalah harga saham pada saat penutupan. Kembalinya ekspektasi untuk menghitung abnormal return dihitung dengan menggunakan model market adjusted. Teknik pengambilan sampel menggunakan teknik purposive sampling, dan diperoleh sebanyak 15 perusahaan yang memenuhi kriteria sampel. Pengujian hipotesis penelitian ini menggunakan uji deskriptif, uji beda satu sampel t-test, dan paired sample t-test. Hasil pengujian hipotesis menunjukkan bahwa terdapat perbedaan rata - rata harga saham positif dan rata - rata abnormal return positif sebelum dan selama pengumuman ARA (H1 dan H4). Tidak ada perbedaan yang signifikan ratarata harga saham positif dan abnormal return positif pada dan sesudahnya, serta sebelum dan sesudah pengumuman ARA (H2, H3, H5 dan H6). Dengan demikian penelitian ini menunjukkan bahwa ARA berpengaruh terhadap nilai perusahaan pada saat sebelum dan selama pengumuman saja.
\end{abstract}

Kata kunci: Annual Report Award (ARA), harga saham, abnormal return.

\section{THE EFFECT OF ANNUAL REPORT AWARD (ARA) ON THE VALUE OF THE COMPANY}

\author{
${ }^{1}$ Dewi Kusuma Wardani, ${ }^{2}$ Diniari Marlina Antara \\ ${ }^{12}$ Program Studi Akuntansi, Fakultas Ekonomi \\ Universitas Sarjanawiyata Tamansiswa Yogyakarta \\ Email: dewifeust@gmail.com
}

\begin{abstract}
This study aims to determine the effect of the Annual Report Award (ARA) on the value of companies in companies that won ARA 2013-2015 listed on the Indonesia Stock Exchange. This research is a research event study for 11 days that is 5 days before, 1 day of the announcement, and 5 days after the announcement. The value of the company in this study is measured by using stock prices and abnormal return. The stock price used is the stock price at closing time. Return of expectation to calculate abnormal return is calculated using market adjusted model. Sampling technique using purposive sampling technique, and obtained as many as 15 companies that meet the criteria of the sample. Hypothesis testing of this research using descriptive test, test different one sample t-test, and paired sample t-test. The result of hypothesis testing shows that there is difference of positive stock price average and positive average abnormal return before and during ARA announcement $(\mathrm{H} 1$ and $\mathrm{H} 4)$. There is no significant difference in average positive stock prices and positive abnormal returns on and after, as well as before and after the announcement of ARA (H2, H3, H5 and H6). Thus this research indicates that ARA has an effect on to company value at time before and during announcement only.
\end{abstract}

Keywords: Annual Report Award (ARA), stock price, abnormal return.

\section{PENDAHULUAN}

Pasar Modal menurut Undang-

Undang No. 8 tahun 1995 adalah kegiatan yang bersangkutan dengan penawaran umum dan perdagangan efek, perusahaan publik yang berkaitan dengan efek yang 
diterbitkannya, serta lembaga dan profesi yang berkaitan dengan efek. Pasar modal memiliki peran penting dalam perekonomian karena dapat menjadi sarana pendanaan bagi perusahaan dan sebagai sarana bagi para investor melakukan investasi (Aristiawan dan Ardiana, 2015:483). Nilai perusahaan dapat dilihat dari harga saham dan abnormal return. Semakin tinggi harga saham semakin tinggi nilai perusahaan dan nilai perusahaan yang tinggi menjadi keinginan para pemilik perusahaan, sebab dengan nilai yang tinggi menunjukkan kemakmuran pemegang saham juga tinggi (Hermuningsih \& Wardani, 2009:175 dan Wardani \& Hermuningsih, 2011:34). Begitu juga dengan abnormal return, abnormal return digunakan untuk mengetahui seberapa besar reaksi pasar (Darmawan, 2015:19). Jika abnormal return positif maka return realisasiannya lebih besar dari return ekspektasian, dan situasi ini akan mengakibatkan investor tertarik untuk bertransaksi di sekitar periode pengumuman dengan harapan mendapatkan keuntungan di atas normal (Aristiawan dan Ardiana, 2015:486).

Ada dua hal yang dapat mempengaruhi pergerakan harga saham dan abnormal return, yaitu dari segi ekonomi dan non ekonomi (Ekawati, 2011:1). Pada penelitian ini, yang mempengaruhi nilai perusahaan difokuskan pada faktor non ekonomi, yaitu penghargaan atas kemenangan meraih Annual Report Award (ARA) 2013-2015. Jumlah peserta ARA pun meningkat tiap tahunnya.

Tabel 1. Jumlah Peserta Annual Report Award 2013-2015

\begin{tabular}{|c|c|c|c|c|}
\hline EVENT & WAKTU \& TEMPAT & TEMA $E V E N T$ & $\begin{array}{c}\text { PERIODE } \\
\text { PENDAFTARAN }\end{array}$ & JUMLAH PESERTA \\
\hline $\begin{array}{c}\text { Annual Report } \\
\text { Award (ARA) } \\
2013\end{array}$ & $\begin{array}{l}\text { 16 Oktober } 2014 \text { di Hotel } \\
\text { Ritz Carlton, Pacific Place, } \\
\text { Jakarta Selatan. }\end{array}$ & $\begin{array}{l}\text { "Membangun Daya Saing Ekonomi } \\
\text { Indonesia Untuk Menyongsong } \\
\text { Integrasi Ekonomi ASEAN } 2015 \\
\text { Melalui Transparansi Informasi” }\end{array}$ & $\begin{array}{c}\text { 28 Maret }-16 \text { Mei } \\
2014 \text { dan } 19 \text { Mei }-4 \\
\text { Juli } 2014\end{array}$ & 261 peserta \\
\hline $\begin{array}{c}\text { Annual Report } \\
\text { Award (ARA) } \\
2014\end{array}$ & $\begin{array}{l}22 \text { September } 2015 \text { di Hotel } \\
\text { Ritz Carlton, Pacific Place, } \\
\text { Jakarta Selatan. }\end{array}$ & $\begin{array}{l}\text { "Akuntabilitas dan Transparansi } \\
\text { Informasi untuk Memenangkan } \\
\text { Persaingan Bisnis dalam Era Integrasi } \\
\text { Ekonomi ASEAN" }\end{array}$ & $\begin{array}{l}9 \text { Februari - } 30 \text { April } \\
2015 \text { dan } 1 \text { Mei - } 6 \text { Juli } \\
2015\end{array}$ & 294 peserta \\
\hline $\begin{array}{c}\text { Annual Report } \\
\text { Award (ARA) } \\
2015\end{array}$ & $\begin{array}{l}27 \text { September } 2016 \mathrm{di} \\
\text { Gedung Dhanapala } \\
\text { Kementerian Keuangan RI, } \\
\text { Jakarta. }\end{array}$ & $\begin{array}{c}\text { "Kualitas Keterbukaan Informasi } \\
\text { Untuk mendukung Kinerja Perusahaan } \\
\text { Secara Berkelanjutan Dalam } \\
\text { Memenangkan Persaingan Global" }\end{array}$ & $\begin{array}{l}25 \text { Januari-29 April } \\
2016 \text { dan } 2 \text { Mei- } 1 \\
\text { Juli } 2016\end{array}$ & 303 peserta \\
\hline
\end{tabular}

Sumber: ojk.go.id dan sumber lain yang terkait

Dari tabel diatas menunjukkan jumlah peserta ARA yang terus meningkat khususnya ARA 2013 hingga 2015. Hal ini menunjukkan bahwa ARA adalah event besar yang sangat diminati oleh berbagai perusahaan, karena dengan memenangkan ARA berarti perusahaan tersebut telah memenuhi kriteria kelengkapan dalam penyajian laporan keuangan dan berhasil menerapkan Good Corporate Governance 
dengan baik (Kemala dan Ulupui, 2015:172-173). Good Corporate Governance sendiri menurut Komite Nasional Good Corporate Governnace (KNGCG), adalah pola hubungan, sistem serta proses yang digunakan organ perusahaan (direksi dan komisaris) guna memberi nilai tambah kepada pemegang saham secara berkesinambungan dalam jangka panjang, berlandaskan peraturan perundangan dan norma yang berlaku dengan tetap memperhatikan kepentingan stakeholder lainnya (Darmawan, 2015:11). Perusahaan yang telah menerapkan Good Corporate Governance akan menghasilkan laporan keuangan yang baik dan akurat (Fatharani, 2014:4). Pengaruh kemenangan meraih ARA seharusnya dapat berpengaruh positif terhadap nilai perusahaan, sejalan dengan hasil penelitian terdahulu yang dilakukan oleh Darmawan (2015:ii).

Perbedaaan hasil penelitian juga ditunjukkan oleh penelitian-penelitian sebelumnya. Penelitian yang dilakukan Darmawan (2015:ii) menunjukkan terdapat pengaruh signifikan pengumuman ARA yang menyebabkan perbedaan harga saham, abnormal return, dan volume perdagangan saham sebelum dan sesudah pengumuman. Berbeda dengan penelitian yang dilakukan Aristiawan dan Ardiana (2015:497) menunjukkan bahwa pengumuman ARA tidak memiliki kandungan informasi dan tidak terdapat perbedaan abnormal return yang signifikan antara sebelum dan setelah pengumuman ARA. Pada penelitian Darmawan (2015) sampel diambil pada ARA periode 2009-2012, sedangkan pada penelitian ini sampel diambil dari perusahaan pemenang ARA 2013-2015 yang terdaftar di Bursa Efek Indonesia. Dari latar belakang tersebut, penelitian ini diberi judul "Pengaruh Annual Report Award (ARA) Terhadap Nilai Perusahaan (Event Study pada Perusahaan Peraih ARA 20132015 yang Terdaftar Di Bursa Efek Indonesia)".

\section{Signalling Theory}

Menurut Darmawan (2015:9), informasi merupakan hal yang penting bagi investor dan pelaku bisnis karena dari sebuah informasi, investor dan pelaku bisnis akan mendapatkan gambaran mengenai keadaan pasar baik di masa yang lalu maupun di masa yang akan datang. Informasi adalah segala pemberitaan, baik di dalam pasar modal maupun di luar pasar modal yang diterima investor dengan harapan dapat digunakan sebagai dasar pengambilan keputusan investasi yang efisien (Wirajaya, 2011:3). Suatu informasi erat kaitannya dengan teori sinyal (signaling theory). Pada dasarnya signaling theory menitikberatkan pada setiap informasi yang dapat memberikan petunjuk bagi investor untuk mengetahui prospek perusahaan di masa mendatang sehingga informasi tersebut akan mempengaruhi penilaian investor terhadap harga saham perusahaan tersebut (Makaryanawati, 2012:198).

Jika informasi memberikan sinyal positif terhadap pasar, reaksi pasar akan ditunjukkan dengan adanya perubahan harga saham dimana harga saham semakin naik. Sebaliknya, jika informasi memberikan sinyal negatif terhadap pasar, reaksi pasar akan ditunjukkan dengan tidak adanya perubahan harga saham yang mana harga saham tetap atau lebih buruknya 
mengalami penurunan (Darmawan, 2015:10). Salah satu informasi yang dapat dijadikan sinyal adalah pengumuman penghargaan yang dilakukan oleh suatu perusahaan. Pada penelitian ini informasi atas kemenangan meraih penghargaan ARA dapat menjadi sinyal positif. Pengumuman ARA merupakan informasi yang memberikan sinyal positif bahwa perusahaan yang memenangkan penghargaan mempunyai prospek yang baik di masa yang akan datang sehingga dapat menarik investor untuk melakukan pembelian saham (Darmawan, 2015:10).

Pengaruh Annual Report Award 20132015 Terhadap Nilai Perusahaan

Dengan kemenangan pada suatu ajang penghargaan, biasanya perusahaan dipandang baik dan berhasil oleh investor/calon investor. Ini ditunjukkan dengan adanya respon positif oleh pasar. Respon positif diasumsikan dengan meningkatnya kepercayaan masyarakat bahwa konsep pembagian Annual Report Award dapat meningkatkan profesionalisme perusahaan dalam mengelola manajemennya dan kualitas laporan keuangan yang lebih baik setiap tahunya, serta menjaga kesejahteraan pemegang saham tanpa mengabaikan kepentingan pihak-pihak lain yang berkepentingan (Ekawati, 2011:41). Penelitian Darmawan (2015:ii) mengindikasikan adanya kepercayaan investor terhadap konsep good corporate governance yang melandasi penghargaan tersebut, akan membuat perusahaan dikelola dengan lebih profesional dan dapat meningkatkan kesejahteraan pemiliknya. Apabila pasar merespon positif pengumuman ARA, hal ini dapat menyebabkan kenaikan rata-rata harga saham dan abnormal return baik sebelum dan saat pengumuman, saat dan sesudah pengumuman, maupun sebelum dan sesudah pengumuman.

\section{Penelitian Ekawati (2011:41)} menyatakan bahwa ARA berpengaruh signifikan terhadap harga saham perusahaan peraih penghargaan setelah pengumuman. Hasil penelitian Darmawan (2015:44) menyatakan bahwa ARA berpengaruh terhadap harga saham yang menyebabkan perbedaan harga saham sebelum dan sesudah pengumuman. Darmawan (2015:44) juga menyatakan, perusahaan yang memenangkan penghargaan mempunyai propsek yang baik di masa yang akan datang sehingga dapat menarik investor untuk melakukan pembelian saham. Pada penelitian Harahap dan Hairunnisah (2017:39) menyatakan terdapat pengaruh signifikan antara GCG terhadap harga saham pada perusahaan perbankan di BEI. Keberhasilan meraih ARA berpengaruh positif terhadap nilai perusahaan juga ditunjukkan pada penelitian Sari dan Sedianingsih (2014:163). Dalam penelitian tersebut juga disebutkan bahwa perusahaan yang menerapkan GCG dengan baik akan mendapat respon yang positif dari pasar sehingga harga sahamnya cenderung meningkat. Berbeda dengan penelitian Makaryanawati (2012:202) yang menemukan bahwa tidak terdapat perbedaan harga saham sebelum dan setelah pengumuman Corporate Governance Perception Index.

Pengaruh ARA terhadap nilai perusahaan yang diukur dengan abnormal 
return juga ditunjukkan pada penelitian Darmawan (2015:45) yang menemukan adanya perbedaan abnormal return sebelum dan sesudah pengumuman ARA. Abnormal return yang signifikan juga ditunjukkan pada penelitian Fatharani (2014:ii) yang meneliti tentang reaksi pasar terhadap pengumuman ARA terhadap abnormal return pada saham syariah. Sejalan dengan penelitian Wirajaya (2011:25) yang menunjukkan adanya abnormal return yang signifikan disekitar tanggal pengumuman Corporate Governance Perception Index pada perusahaan yang mengikuti survei penerapan corporate governance, dan penelitian Bozcuk (2010:6) yang membuktikan adanya abnormal return signifikan atas pengumuman informasi corporate governance baik di Brazil maupun Turki, yang merupakan negara dengan efisiensi pasar modal serupa dengan Indonesia. Berbeda dengan hasil penelitian Aristiawan dan Ardiana (2015:497) serta Apriyanti dan Sidanti (2016:91) yang menyatakan tidak terdapat perbedaan abnormal return yang siginfikan sebelum dan setelah pengumuman. Penelitian Kemala dan Ulupui (2015:171) juga menunjukkan tidak adanya abnormal return yang signifikan sebelum dan setelah publikasi ARA. Dengan demikian hipotesis untuk pengaruh ARA terhadap nilai perusahaan yang diukur dengan harga saham dan abnormal return yaitu:

$\mathrm{H} 1$ = Terdapat perbedaan rata-rata harga saham positif sebelum dan saat pengumuman ARA 20132015.
$\mathrm{H} 2=$ Terdapat perbedaan rata-rata harga saham positif saat dansesudah pengumuman ARA 2013-2015.

H3 = Terdapat perbedaan rata-rata harga saham positif sebelum dan sesudah pengumuman ARA 2013-2015.

$\mathrm{H} 4=$ Terdapat perbedaan rata-rata abnormal return positif sebelum dan saat pengumuman ARA 2013-2015.

$\mathrm{H} 5=$ Terdapat perbedaan rata-rata abnormal return positif saat dan sesudah pengumuman ARA 2013-2015.

H6 = Terdapat perbedaan rata-rata abnormal return positif sebelum dan sesudah pengumuman ARA 2013-2015.

\section{METODE}

\section{Populasi dan Sampel}

Populasi dalam penelitian ini adalah perusahaan-perusahaan go public yang terdaftar di Bursa Efek Indonesia dan mengikuti ARA 2013-2015. Sampel yang digunakan dalam penelitian ini adalah perusahaan-perusahaan go public di Bursa Efek Indonesia yang memenuhi kritertia untuk dijadikan sebagai sampel. Teknik pengambilan sampel dalam penelitian ini dengan menggunakan metode purposive sampling, yaitu pengambilan sampel berdasarkan kriteria tertentu. Didapatkan perusahaan yang memenuhi kriteria adalah 15 perusahaan.

\section{METODE ANALISIS DATA}

Analisis Event Study 
Dalam penelitian ini dilakukan event study selama 11 hari, yaitu 5 hari sebelum ARA, 1 hari saat peristiwa, dan 5 hari sesudah peristiwa ARA. Berikut prosedur metode event study:

a. Menentukan event atau peristiwa yang akan diteliti. Pada penelitian ini adalah ARA 2013-2015.

b. Mengidentifikasi tanggal pengumuman event/peristiwa.

c. Menentukan panjang periode penelitian. Dalam penelitian ini menggunakan periode penelitian selama 11 hari yaitu 5 hari sebelum, 1 hari saat pengumuman, dan 5 hari sesudah pengumuman. Pada penelitian ini tidak menggunakan periode estimasi.

d. Menentukan populasi dan sampel penelitian. Populasi dalam penelitian ini adalah perusahaan go public yang terdaftar di BEI dan mengikuti ARA 2013-2015. Sampel yang digunakan adalah perusahaan yang memenuhi persyaratan metode purposive sampling.

e. Menghitung rata-rata harga saham dan abnormal return.

\section{Uji Normalitas Data}

Pengujian normalitas data dilakukan karena merupakan syarat dari uji t yang mengharuskan data berdistribusi normal. Uji normalitas menguji apakah data terdistribusi secara normal atau tidak. Pengujian normalitas data menggunakan uji Kolmogorov-Smirnov. Dalam pengujian One Sample Kolmogorov-Smirnov ditetapkan taraf signifikan 0,05 atau 5\%. Dasar pengambilan dari One Sample
Kolmogorov Smirnov dilakukan dengan membuat hipotesis:

$\mathrm{H}_{0}=$ data berdistribusi secara normal

$\mathrm{H}_{1}=$ data tidak berdistribusi secara normal $\mathrm{H}_{0}$ terdukung apabila nilai signifikan lebih dari 0,05 dan $\mathrm{H}_{1}$ terdukung apabila nilai signifikansi kurang dari 0,05 .

\section{Analisis Uji Beda One Sample T-Test dan Paired Sample T-Test}

Pada penelitian ini menggunakan analisis uji beda yaitu one sample t-tes dan paired sample t-tes. Uji one sample t-test, menguji apakah suatu nilai tertentu (yang diberikan sebagai pembanding) berbeda secara nyata ataukah tidak dengan rata-rata sebuah sampel (Djarwanto, 1999:89). Pada penelitian ini pengujian one sampel t-test digunakan untuk menguji beda rata-rata harga saham maupun abnormal return antara sebelum pengumuman dengan saat pengumuman, kemudian menguji beda antara saat pengumuman dengan sesudah pengumuman. Pengujian paired sample ttest, merupakan prosedur yang digunakan untuk membandingkan rata-rata dua variabel dalam satu grup (Aksa, 2015:13). Untuk menguji rata-rata harga saham atau abnormal return sebelum dengan sesudah pengumuman perlu menggunakan uji paired sample t-test, karena pengujian ini digunakan untuk menguji perbedaan ratarata dua sampel yang berhubungan. Dalam penelitian ini, rata-rata dua sampel yang berhubungan yaitu rata-rata harga saham dan abnormal return sebelum dengan sesudah pengumuman.

\section{HASIL DAN PEMBAHASAN}

Uji Normalitas Data 
Berdasarkan hasil uji normalitas data menunjukkan, hasil untuk rerata harga saham sebelum ARA 2013-2015 memiliki nilai signifikansi $0,910>0,005$ dan signifikansi rerata harga saham sesudah ARA 2013-2015 sebesar 0,776>0,005. Begitu juga dengan rerata abnormal return sebelum ARA 2013-2015 memiliki signfikansi 0,812 >0,005 dan signifikansi rerata abnormal return sesudah ARA 20132015 adalah 0,992>0,05. Dengan demikian untuk sampel rerata harga saham dan abnormal return baik sebelum maupun sesudah ARA 2013-2015 berdistribusi normal, sehingga $\mathrm{H}_{0}$ terdukung dan $\mathrm{H}_{1}$ ditolak.

\section{Pengujian Hipotesis}

Pengujian Hipotesis ke-1
Hipotesis pertama berbunyi, terdapat perbedaan rata-rata harga saham positif sebelum dan saat pengumuman ARA 20132015. Pengujian hipotesis pertama dilakukan menggunakan one sample t-test. Ditunjukkan pada tabel 3 untuk rerata harga saham sebelum ARA diperoleh nilai thitung sebesar $-11,165$ dengan nilai signifikansi (2-tailed) sebesar 0,000. Tingkat signifikansi sebesar $0,000<$ dari 0,05 maka dapat dikatakan terdapat perbedaan signifikan rata-rata harga saham sebelum dan saat pengumuman. Berdasarkan tabel 2 dapat diketahui nilai mean rata-rata harga saham sebelum ARA sebesar 2.637,8933 dan rata-rata harga saham saat pengumuman yaitu 2.660,733333 (pada tabel 3). Berikut tabel hasil pengujian:

Tabel 2. One-Sample Statistics Harga Saham Sebelum ARA 2013-2015

\begin{tabular}{lcccc}
\hline & & & Std. & Std. Error \\
& $N$ & Mean & Deviation & Mean \\
\hline hs_sebelum_ARA & 5 & $2.637,8933$ & 4,57447 & 2,04577 \\
\hline
\end{tabular}

Sumber: Output SPSS 15, 2017

Tabel 3. One-Sample Test Harga Saham Sebelum ARA 2013-2015

\begin{tabular}{ccccccc}
\hline & \multicolumn{7}{c}{ Test Value $=2660.733333$} \\
\cline { 2 - 7 } & & \multicolumn{7}{c}{ Sig. $(2-$} & Mean & 95\% Confidence Interval \\
\cline { 5 - 7 } & $t$ & $d f$ & tailed) & Difference & Lower & Upper \\
\hline hs_sebelum_ARA & $-11,165$ & 4 & 0,000 & $-22,84000$ & $-28,5200$ & $-17,1600$ \\
\hline
\end{tabular}

Sumber: Output SPSS 15, 2017

Hasil pengujian diatas menunjukkan adanya kenaikan positif rata-rata harga saham saat pengumuman dibanding sebelum pengumuman, hal ini menunjukkan terdapat perbedaan rata-rata harga saham positif yang signifikan sebelum dan saat pengumuman ARA. Dengan demikian hipotesis 1 terdukung.

\section{Pengujian Hipotesis ke-2}

Hipotesis kedua berbunyi, terdapat perbedaan rata-rata harga saham positif saat dan sesudah pengumuman ARA 2013-2015. Pengujian hipotesis 2 menggunakan one sample t-test. Dapat ditunjukkan pada tabel 5, rata-rata harga saham sesudah ARA memiliki nilai t-hitung sebesar $-3,258$ 
dengan signifikansi (2-tailed) sebesar 0,031. Nilai signifikansi (2-tailed) lebih kecil dari 0,05 menunjukkan adanya perbedaan signifikan sesudah pengumuman. Terlihat dari tabel 5 nilai mean saat pengumuman sebesar 2660,733333 dan nilai mean harga saham sesudah ARA sebesar 2.639,4933 (tabel 4). Berikut tabel hasil pengujian:

Tabel 4. One-Sample Statistics Harga Saham Sesudah ARA 2013-2015

\begin{tabular}{lcccc}
\hline & & & Std. & Std. Error \\
& $N$ & Mean & Deviation & Mean \\
\hline hs_sesudah_ARA & 5 & $2.639,4933$ & 14,57743 & 6,51922 \\
\hline
\end{tabular}

Sumber: Output SPSS 15, 2017

Tabel 5. One-SampleTest Harga Saham Sesudah ARA 2013-2015

\begin{tabular}{lcccccc}
\hline & \multicolumn{7}{c}{ Test Value $=2660.733333$} \\
\cline { 2 - 5 } & $t$ & $d f$ & Sig. $(2-$ & Mean & \multicolumn{2}{c}{$95 \%$ Confidence Interval } \\
\cline { 5 - 7 } & & tailed $)$ & Difference & Lower & Upper \\
\hline hs_sesudah_ARA & $-3,258$ & 4 & 0,031 & $-21,24000$ & $-39,3403$ & $-3,1397$ \\
\hline
\end{tabular}

Sumber: Output SPSS 15, 2017

Hasil pengujian menunjukkan terdapat penurunan negatif rata-rata harga saham sesudah pengumuman, terlihat dari nilai mean sesudah pengumuman lebih kecil daripada saat pengumuman. Dengan demikian dapat dikatakan terdapat perbedaan rata-rata harga saham negatif yang signifikan antara saat dan sesudah pengumuman. Dari hasil ini maka hipotesis ke-2 ditolak.

\section{Pengujian Hipotesis ke-3}

Hipotesis ketiga berbunyi, terdapat perbedaan rata-rata harga saham positif sebelum dan sesudah pengumuman ARA
2013-2015. Pengujian hipotesis ke-3 ini menggunakan uji beda paired sample t-test atau uji $\mathrm{t}$ berpasangan. Pada tabel 7 didapatkan hasil rata-rata harga saham memiliki nilai t-hitung sebesar $-0,199$ dengan signifikansi (2-tailed) sebesar 0,852. Nilai signifikansi $0,852>$ dari 0,05 yang berarti tidak terdapat perbedaan yang signifikan antara sebelum dan sesudah pengumuman. Hasil deskriptif pada tabel 6 menyatakan rata-rata harga saham sebelum memiliki nilai mean sebesar 2.637,8933 dan rata-rata harga saham sesudah memiliki nilai mean sebesar 2.639,4933. Berikut tabel hasil pengujian:

Tabel 6. Paired Sample Statistics Harga Saham Sebelum dan Sesudah ARA 2013-2015

\begin{tabular}{llcccc}
\hline & & & \multicolumn{2}{c}{ Std. } & \multicolumn{2}{c}{ Std. Error } \\
& & Mean & $N$ & Deviation & Mean \\
\hline Pair 1 & hs_sebelum_ARA & $2.637,8933$ & 5 & 4,57447 & 2,04577 \\
& hs_sesudah_ARA & $2.639,4933$ & 5 & 14,57743 & 6,51922 \\
\hline
\end{tabular}

Sumber: Output SPSS 15, 2017 
Tabel 7 Paired Sample Test Harga Saham Sebelum dan Sesudah ARA 2013-2015

\begin{tabular}{|c|c|c|c|c|c|c|c|c|}
\hline & \multicolumn{5}{|c|}{ Paired Differences } & \multirow[b]{3}{*}{$t$} & \multirow[b]{3}{*}{$d f$} & \multirow{3}{*}{$\begin{array}{l}\text { Sig. (2- } \\
\text { tailed) }\end{array}$} \\
\hline & \multirow[b]{2}{*}{ Mean } & \multirow{2}{*}{$\begin{array}{c}\text { Std. } \\
\text { Deviation }\end{array}$} & \multirow{2}{*}{$\begin{array}{c}\text { Std. Error } \\
\text { Mean } \\
\end{array}$} & \multicolumn{2}{|c|}{ 95\% Confidence Interval } & & & \\
\hline & & & & Upper & Lower & & & \\
\hline Pair 1 hs_sebelum_ARA-hs_sesudah_ARA & $-1,60000$ & 17,95024 & 8,02759 & $-23,88817$ & 20,68817 & $-0,199$ & 4 & 0,852 \\
\hline
\end{tabular}

Sumber: Output SPSS 15, 2017

Hasil pengujian menunjukkan adanya kenaikan positif rata-rata harga saham antara sebelum dan sesudah pengumuman. Ini menunjukkan terdapat kenaikan positif ratarata harga saham sebelum dan sesudah pengumuman, tetapi kenaikan tersebut tidak signifikan. Dengan demikian hipotesis ke-3 ditolak.

\section{Pengujian Hipotesis ke-4}

Hipotesis keempat berbunyi, terdapat perbedaan rata-rata abnormal return positif sebelum dan saat pengumuman ARA 20132015. Pengujian hipotesis ke-4 menggunakan one sample t-test. Dari tabel 9 ditunjukkan rata-rata abnormal return sebelum ARA memiliki nilai t-hitung sebesar -4,090 dengan signifikansi (2-tailed) sebesar 0,015. Signifikansi (2-tailed) 0,015 $<0,05$ yang berarti terdapat perbedaan yang signifikan rerata abnormal return antara sebelum dan saat pengumuman ARA. Tabel 8 juga menunjukkan rerata abnormal return sebelum pengumuman memiliki nilai mean sebesar -0,0026 dan rerata abnormal return saat pengumuman sebesar 0,004225767 (pada tabel 9). Berikut tabel hasil pengujian:

Tabel 8. On-Sample Statistic Abnormal ReturnSebelum dan Saat ARA 2013-2015

\begin{tabular}{|c|c|c|c|c|}
\hline & $N$ & Mean & $\begin{array}{c}\text { Std. } \\
\text { Deviation }\end{array}$ & $\begin{array}{c}\text { Std. Error } \\
\text { Mean }\end{array}$ \\
\hline $\begin{array}{l}\text { ar_sebelum } \\
\text { ARA }\end{array}$ & 5 & $-0,0026$ & 0,00375 & 0,00167 \\
\hline
\end{tabular}

Sumber: Output SPSS 15, 2017

Tabel 9. One-Sample TestAbnormal Return Sebelum dan Saat ARA 2013-2015

\begin{tabular}{lcccccc}
\hline & \multicolumn{6}{c}{ Test Value $=0.004225767$} \\
\cline { 2 - 7 } & \multicolumn{7}{c}{$t$} & $d f$ & $\begin{array}{c}\text { Sig. (2- } \\
\text { tailed) }\end{array}$ & $\begin{array}{c}\text { Mean } \\
\text { Difference }\end{array}$ & \multicolumn{2}{c}{ 95\% Cower } & Upper \\
\hline ar_sebelum_- & $-4,090$ & 4 & 0,015 & $-0,00685$ & $-0,0115$ & $-0,0022$ \\
ARA & & 4 & & &
\end{tabular}

Sumber: Output SPSS 15, 2017

Hasil pengujian menunjukkan nilai mean rerata abnormal return sebelum lebih kecil dari saat pengumuman, yang berarti terjadi kenaikan positif rerata abnormal return saat pengumuman. Dapat disimpulkan terdapat perbedaan rata-rata abnormal return positif yang signifikan sebelum dan saat pengumuman ARA. Hal ini berarti hipotesis ke-4 diterima.

\section{Pengujian Hipotesis ke-5}

Hipotesis kelima berbunyi, terdapat perbedaan rata-rata abnormal return positif saat dan sesudah pengumuman ARA 2013- 
2015. Pengujian hipotesis menggunakan uji one sample t-test. Hasil pengujian (tabel 11) menunjukkan rerata abnormal return saat dan sesudah pengumuman memiliki nilai thitung sebesar -2,015 dengan signifikansi (2-tailed) sebesar 0,114. Signifikansi (2tailed) sebesar 0,114>0,005 menunjukkan tidak terdapat beda yang signifikan antara saat dan sesudah pengumuman ARA. Dari tabel 11 nilai mean saat pengumuman sebesar 0,004225767 dan dari tabel 10 juga ditunjukkan nilai mean rerata abnormal return sesudah pengumuman sebesar 0,0046. Berikut disajikan tabel hasil pengujian:

Tabel 10. On-Sample StatiticsAbnormal Return Saat dan Sesudah ARA 2013-2015

\begin{tabular}{|c|c|c|c|c|}
\hline & $N$ & Mean & $\begin{array}{c}\text { Std. } \\
\text { Deviation }\end{array}$ & $\begin{array}{c}\text { Std. Error } \\
\text { Mean }\end{array}$ \\
\hline $\begin{array}{l}\text { ar_sesudah_ } \\
\text { ARA }\end{array}$ & 5 & $-0,0046$ & 0,00982 & 0,00439 \\
\hline
\end{tabular}

Sumber: Output SPSS 15, 2017

Tabel 11. On-Sample TestAbnormal Return Saat dan Sesudah ARA 2013-2015

\begin{tabular}{|c|c|c|c|c|c|c|}
\hline & \multicolumn{6}{|c|}{ Test Value $=0.004225767$} \\
\hline & \multirow[b]{2}{*}{$t$} & \multirow[b]{2}{*}{$d f$} & \multirow{2}{*}{$\begin{array}{l}\text { Sig. (2- } \\
\text { tailed) }\end{array}$} & \multirow{2}{*}{$\begin{array}{c}\text { Mean } \\
\text { Difference }\end{array}$} & \multicolumn{2}{|c|}{$95 \%$ Confidence } \\
\hline & & & & & Lower & Upper \\
\hline $\begin{array}{l}\text { ar_sesudah_ } \\
\text { ARA }\end{array}$ & $-2,015$ & 4 & 0,114 & $-0,00885$ & $-0,0210$ & 0,0033 \\
\hline
\end{tabular}

Sumber: Output SPSS 15, 2017

Hasil pengujian menjelaskan bahwa nilai mean sesudah pengumuman lebih kecil daripada saat pengumuman, ini menunjukkan adanya penurunan negatif rerata abnormal return. Dapat disimpulkan bahwa terdapat perbedaan rerata abnormal return negatif yang tidak signifikan antara saat dan sesudah pengumuman. Dengan demikian hipotesis ke-5 ditolak.

\section{Pengujian Hipotesis ke-6}

Hipotesis keenam berbunyi, terdapat perbedaan rata-rata abnormal return positif sebelum dan sesudah pengumuman ARA 2013-2015. Pengujian hipotesis ke-6 menggunakan uji paired sample t-test. Terlihat dari tabel 13, rata-rata abnormal return sebelum dan sesudah memiliki nilai t-hitung 0,420 dengan signifikansi (2-tailed) sebesar 0,696. Signifikansi (2-tailed) sebesar 0,696 > dari 0,05 yang berarti tidak terdapat perbedaan signifikan sebelum dan sesudah pengumuman ARA. Dari tabel 12 menunjukkan nilai mean rata-rata abnormal return sebelum ARA sebesar -0,0026 dan sesudah ARA sebesar -0,0046. Berikut tabel hasil pengujian:

Hasil pengujian menunjukkan bahwa terdapat penurunan negatif rata-rata abnormal return sebelum dan sesudah pengumuman, namun penurunan ini tidak signifikan. Ditunjukan pada nilai mean sesudah ARA lebih kecil daripada sebelum ARA. Dapat disimpulkan bahwa terdapat perbedaan rata-rata abnormal return negatif 
Tabel 12. Paired Sample Statistics Abnormal Return Sebelum dan Sesudah ARA 20132015

\begin{tabular}{rcccc}
\hline & & \multicolumn{2}{c}{ Std. } & \multicolumn{2}{c}{ Std. Error } \\
& Mean & $N$ & Deviation & Mean \\
\hline Pair 1 ar_sebelum_ARA & $-0,0026$ & 5 & 0,00375 & 0,00167 \\
ar_sesudah_ARA & $-0,0046$ & 5 & 0,00982 & 0,00439 \\
\hline
\end{tabular}

Sumber: Output SPSS 15, 2017

Tabel 13. Paired Sample Test Abnormal Return Sebelum dan Sesudah ARA 2013-2015

\begin{tabular}{|c|c|c|c|c|c|c|c|c|}
\hline & \multicolumn{5}{|c|}{ Paired Differences } & \multirow[b]{3}{*}{$t$} & \multirow[b]{3}{*}{$d f$} & \multirow{3}{*}{$\begin{array}{l}\text { Sig. }(2 . \\
\text { tailed) }\end{array}$} \\
\hline & \multirow[b]{2}{*}{ Mean } & \multirow{2}{*}{$\begin{array}{c}\text { Std. } \\
\text { Deviation }\end{array}$} & \multirow{2}{*}{$\begin{array}{c}\text { Std. Error } \\
\text { Mean }\end{array}$} & \multicolumn{2}{|c|}{$95 \%$ Confidence } & & & \\
\hline & & & & Upper & Lower & & & \\
\hline Pair 1 ar_sebelum_ARA - ar_sesudah_ARA & 0,00200 & 0,01066 & 0,00477 & $-0,01123$ & 0,01523 & 0,420 & 4 & 0,696 \\
\hline
\end{tabular}

Sumber: Output SPSS 15, 2017

\section{PEMBAHASAN}

\section{Pengaruh Annual Report Award 2013-} 2015 Terhadap Nilai Perusahaan

Pada penelitian ini ada dua indikator dari nilai perusahaan yang digunakan untuk mengukur pengaruh ARA, yaitu harga saham dan abnormal return. Berikut ini ringkasan hasil pengujian hipotesis:

Tabel 14. Tabel Ringkasan Hasil Pengujian Hipotesis

\begin{tabular}{ccc}
\hline Hipotesis & Harga Saham & Abnormal Return \\
\hline Sebelum dan Saat & H1= Diterima & H4= Diterima \\
Saat dan Sesudah & H2= Ditolak & H5 = Ditolak \\
Sebelum dan & H3 = Ditolak & H6= Ditolak \\
Sesudah & &
\end{tabular}

Sumber: Data Olahan, 2017

Berdasarkan hasil pengujian, untuk indikator harga saham didapatkan ada perbedaan rata-rata positif signifikan pada sebelum dan saat pengumuman. Pada saat dan sesudah, serta antara sebelum dan sesudah pengumuman tidak ada beda positif signifikan. Untuk indikator abnormal return juga didapatkan, ada beda rata-rata positif signifikan pada sebelum dan saat pengumuman. Pada saat dan sesudah, serta antara sebelum dan sesudah tidak didapatkan beda positif signifikan.

Hal ini dapat terjadi karena investor merespon dengan cepat pengumuman tersebut dan kemudian tidak meresponnya lagi setelah pengumuman. Seperti 
penjelasan Jogiyanto (2010:22), periode jendela dapat menangkap efek peristiwa tergantung dari peristiwanya. Penelitian ini membuktikan bahwa ARA merupakan peristiwa yang cepat untuk direspon pasar. Dari hasil ini menunjukkan bahwa ARA berpengaruh terhadap nilai perusahaan pada waktu sebelum dan saat pengumuman saja.

Pengujian ini mendukung penelitian Sari dan Sedianingsih (2014:163) yang menyatakan keberhasilan meraih ARA berpengaruh positif terhadap nilai perusahaan. Hasil penelitian Darmawan (2015:44) menyatakan bahwa ARA berpengaruh terhadap harga saham. Fatharani (2014:ii) yang menunjukkan abnormal return yang signifikan pada pengumuman ARA untuk saham syariah. Pengujian ini tidak mendukung penelitian Darmawan (2015:44) yang menemukan tidak ada abnormal return signifikan pada saat pengumuman.

\section{KESIMPULAN}

Berdasarkan hasil pengujian terhadap hipotesis dengan menggunakan pengujian one sample t-test dan paired sample t-test, maka dapat diambil kesimpulan bahwa hasil penelitian ini menunjukkan bahwa ARA berpengaruh terhadap nilai perusahaan pada waktu sebelum dan saat pengumuman saja. Saran yang dapat disampaikan kepada peneliti selanjutnya yaitu:

a. Penelitian selanjutnya dapat menambah variabel bebas lain seperti kinerja perusahaan.

b. Penelitian selanjutnya dapat menggunakan model lain dalam perhitungan expected return misalnya model sesuaian rerata, market model, dan CAPM.

c. Peneliti selanjutnya dapat menentukan kriteria sampling lebih tepat, misalnya menentukan event lain yang memang berlawanan dengan ARA sehingga tidak banyak sampel yang gugur.

d. Peneliti selanjutnya dapat menambah tahun periode penelitian atau periode jendela.

\section{DAFTAR PUSTAKA}

Adkhari, Siska Yohana., 2017. "Pengaruh Reformasi Suku Bunga Acuan Bank Indonesia Terhadap Abnormal Return dan Trading Volume Activity pada Sektor Perbankan di Bursa Efek Indonesia". Skripsi, Fakultas Ekonomi Universitas Sarjanawiyata Tamansiswa, Yogyakarta.

Apriyanti., dan Heny Sidanti., 2016. "Perbedaan Abnormal Return dan Volume Perdagangan Saham Sebelum dan Setelah Pengumuman Pemenang Award Tahun 2014 pada Perusahaan yang Listing di Bursa Efek Indonesia”. Jurnal Ilmiah Bidang Ilmu Ekonomi, Sekolah Tinggi Ilmu Ekonomi Dharma Iswara Madiun. Vol. 11, No. 2.

“Annual Report Award (ARA 2013)". http://www.bi.go.id/id/ruangmedia/infoterbaru/Pages/ARA 2013.aspx. Diakses pada tanggal 2 November 2016 pukul 16:30.

"Annual Report Award (ARA 2014)". http://www.bi.go.id/id/ruangmedia/info-terbaru/Pages/ARA2014.aspx. Diakses pada tanggal 2 November 2016 pukul 10:06.

“Annual Report Award (ARA 2016)". http://www.ojk.go.id/id/Pages/AnnualReport-Award-2016.aspx.Diakses pada tanggal 17 Maret 2017 pukul 01:00.

Aristiawan, I Gusti Ngurah Agung Dedy., dan Putu Agus A., 2015. "Kandungan Informasi dan Perbedaan Abnormal Return Sebelum dan Setelah Annual 
Report Award". E-Jurnal Akuntansi, Universitas Udayana 11.2. Hal. 483499.

Boedijoewono, Noegroho., 2012. Pengantar Statistika Ekonomi dan Bisnis. UPP STIM YKPN Yogyakarta, Edisi Keenam.

Bozcuk, Aslihan., 2010. "Price Reaction to Corporate Governance Rating Announcements at The Istanbul Stock Exchange". International Journal of Economics and Finance Studies, Faculty of Economics and Administrative Sciences Akdeniz University, Turkey. Vol. 2, No. 1.

Darmawan, Arif Budi., 2015. "Pengaruh Annual Report Award Terhadap Nilai Perusahaan (Event Study pada Perusahaan Peraih ARA 2009-2012)". Skripsi,Universitas Negeri Sebelas Maret, Surakarta.

Djarwanto., 1999. Statistik Nonparametrik. BPFE Yogyakarta, Edisi ketiga.

Ekawati, Rika Kharlina., 2011. "Analisis Perbedaan Harga Saham Sebelum dan Sesudah Pengumuman Annual Report Awards (ARA) di Bursa Efek Jakarta".Jurnal Ilmiah, STIE MDP. Vol. 1, No. 1.

Fatharani, Asifah., 2014. "Reaksi Pasar Terhadap Pengumuman Annual Report Award Terhadap Abnormal Return pada Saham Syariah (Periode 20052013)".Skripsi, Universitas Islam Negeri Sunan Kalijaga, Yogyakarta.

Ghozali, Imam., 2011. Aplikasi Analisis Multivariate dengan Program IBM SPSS 19. Badan Penerbit Universitas Diponegoro Semarang, Edisi Kelima.

Harahap, Dahrul Aman., dan Ade Isyana Hairunnisah., 2017. "Pengaruh NPL, LDR, GCG, NIM, ROA, ROE, CAR, BOPO Terhadap Harga Saham pada Perusahan Perbankan Yang Terdaftar di Bursa Efek Indonesia dari Tahun 2010-2014". Dimensi. Vol. 6, No. 1.

Hermuningsih, Sri dan Wardani, Dewi Kusuma. 2009. "Faktor-faktor yang Mempengaruhi Nilai Perusahaan yang Terdaftar di Bursa Efek Malaysia dan
Bursa Efek Indonesia”. Jurnal Siasat Bisnis, Vol.13, No.2.

Jogiyanto., 2010. Studi Peristiwa. BPFE Yogyakarta, Edisi Pertama.

Kadir., 2015. Statistika Terapan: Konsep, Contoh dan Analisis Data dengan Program SPSS/ Lisrel dalam Penelitian. PT RajaGrafindo Persada Jakarta, Edisi Pertama.

Kemala, Kadek Citra., dan I Gusti Ketut Agung Ulupui., 2015. "Reaksi Pasar Terhadap Publikasi Annual Report Award".E-Jurnal Akuntansi, Universitas Udayana 11.1. Hal: 171185.

Komite Nasional Kebijakan Governance., 2006. Pedoman Umum Good Corporate Governance Indonesia.

Kuncoro, Mudrajad., 2013. Metode Riset Untuk Bisnis dan Ekonomi. Erlangga. Jakarta.

"Live Report ARA: Ini Dia! Perusahaan Pemenang ARA Tahun Buku 2015". http://annualreport.id/info/live-reportara-ini-dia-perusahaan-pemenan-aratahun-buku-2015. Diakses pada tanggal 23 Februari 2017 pukul 16:56.

Makaryanawati., 2012. "Reaksi Investor atas Corporate Governance Perception Index (CGPI) 2011". Jurnal Keuangan dan Perbankan. Vol. 16, No. 2.

"Malam Penganugerahan Annual Report Award (ARA) 2013". www.ojk.go.id/Files/201410/Buatlampi ranflyer 1412754174.pdf. Diakses pada tanggal 2 November 2016 pukul $16: 25$.

"Penghargaan Atas Akuntabilitas dan Transparansi Perusahaan". http://annualreport.id/highlight/pengh argaan-atas-akuntabilitas-dan transpa rasi-perusahaan. Diakses pada tanggal 17 Maret 2017 pukul 01:53.

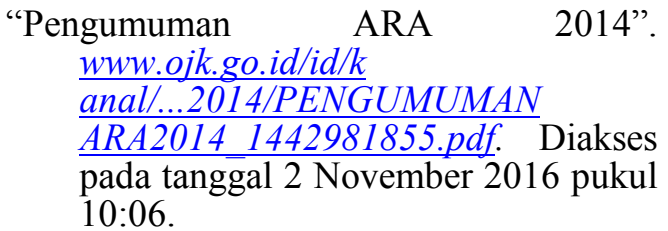


Randy, Vincentius., dan Juniarti., 2013. "Pengaruh Penerapan Good Corporate Governance Terhadap Nilai Perusahan yang Terdaftar di BEI 2007-2011". Business Accounting Review, Akuntansi Bisnis Universitas Kristen Petra. Vol. 1, No. 2.

Sari, Truely Purnama., dan Sedianingsih., 2014. "Pengaruh Good Corporate Governance Terhadap Kinerja Keuangan dan Nilai Perusahaan pada Peserta Survei Corporate Governance Perception Index". Jurnal Ekonomi dan Bisnis, Fakultas Ekonomi dan Bisnis Universitas Airlangga.

Tandelilin, Eduardus., 2010. Portofolio dan Investasi Teori dan Aplikasi. Kanisius Yogyakarta, Edisi Pertama.

Tedjakusuma, Melissa Aristya., 2012. "Studi Beda Reaksi Pasar atas Pengumuman Corporate Governance Perception Index antara Perusahaan "Sepuluh Besar" dan "Non Sepuluh Besar" yang Terdaftar di Bursa Efek Indonesia Tahun 2007-2011”. Jurnal Ilmiah Mahasiswa, Fakultas Bisnis dan Ekonomika Universitas Surabaya. Vol. 1, No. 1.

Pemerintah Indonesia. Undang Undang Republik Indonesia Nomor 8 Tahun 1995 tentang Pasar Modal.

Widianto, Hari Suryono., 2011. "Pengaruh Profitabilitas, Likuiditas, Leverage, Aktivitas, Ukuran Perusahaan, dan Corporate Governance Terhadap Praktik Pengungkapan Sustainability Report (Studi pada PerusahanPerusahaan yang Listed (Go-Public) di Bursa Efek Indonesia (BEI) Periode 2007-2009)". Skripsi, Fakultas Ekonomi Universitas Diponegoro, Semarang.

Wirajaya, I Gede Ary., 2011. "Reaksi Pasar atas Pengumuman Corporate Governance Perception Index (Studi Peristiwa di Bursa Efek Indonesia)". Jurnal, Fakultas Ekonomi Universitas Udayana, Bali.

Wardani, Dewi Kusuma dan Hermuningsih, Sri.2011. "Pengaruh Struktur Kepemilikan Terhadap Nilai Perusahaan Dengan Kinerja Keuangan dan Kebijakan Hutang Sebagai
Variabel Intervening". Jurnal Siasat Bisnis, Vol.15, No.1. 